\title{
Antiphospholipid antibodies in homozygous sickle cell disease
}

\author{
Karel De Ceulaer, Munther A Khamashta, E Nigel Harris, Graham R Serjeant, \\ Graham R V Hughes
}

\begin{abstract}
Serum samples from 108 unselected Jamaican patients with homozygous sickle cell disease and 116 control subjects with normal haemoglobin were screened for the presence of antiphospholipid antibodies.

Slightly increased levels of IgG antiphospholipid antibodies were found in nine patients with sickle cell disease and in none of the control subjects. Serial control samples confirmed the increased levels of antiphospholipid antibodies. A comparison of the haematological and clinical features of patients with positive and negative antiphospholipid sickle cell disease did not highlight any differences between the groups.
\end{abstract}

Antiphospholipid antibodies are known to be associated with repeated episodes of arterial or venous thrombosis, or both, recurrent fetal loss, neurological disease, and possible thrombocytopenia. $^{12}$

In patients with homozygous sickle cell disease, spontaneous abortions occur in up to $24 \%$ of pregnancies. ${ }^{3}$ Central nervous system lesions also often occur, especially hemiplegia, convulsions, and brain stem ischaemia. ${ }^{45}$ Most of these clinical complications may be explained by small blood vessel obstruction by sickle erythrocytes. However, the wide variability of the clinical spectrum of sickle cell disease necessitates consideration of other possible mechanisms. Repeated sickling produces a disruption and rearrangement of red cell membranes. ${ }^{6}$ The exposure of negatively charged phospholipids may result in the induction of antibodies against these cell membrane constituents. Therefore, we screened a large number of patients with sickle cell disease and control subjects with normal haemoglobin for the presence of antiphospholipid antibodies.

Table 1 Haematological parameters in anticardiolipin antibody (aCL) positive and aCL negative patients with sickle cell disease matched for age and sex

\begin{tabular}{|c|c|c|c|c|c|c|}
\hline \multirow[t]{2}{*}{ Parameters } & \multicolumn{3}{|c|}{$a C L$ positive } & \multicolumn{3}{|c|}{ aCL negatiz'e } \\
\hline & $n$ & Mean & $S D$ & $n$ & Me'an & $S D$ \\
\hline Haemoglobin (g/l) & 9 & 91 & 12 & 45 & 90 & 15 \\
\hline $\begin{array}{l}\text { Packed cell volume } \\
\text { Mean cell haemoglobin }\end{array}$ & 9 & 0.26 & 0.46 & 45 & $0 \cdot 27$ & $0 \cdot 44$ \\
\hline concentration $(\mathrm{g} / \mathrm{l})$ & 9 & 352 & 22 & 45 & 332 & 31 \\
\hline Red blood cells $\left(\times 10^{12} / 1\right)$ & 9 & $3 \cdot 1$ & $0 \cdot 7$ & 45 & $3 \cdot 1$ & 0.8 \\
\hline Mean cell volume (fl) & 9 & $86 \cdot 8$ & $10 \cdot 6$ & 45 & $86 \cdot 2$ & $10 \cdot 9$ \\
\hline Platelets $\left(\times 10^{9} / \mathrm{l}\right)$ & 6 & $378 \cdot 7$ & $108 \cdot 1$ & 14 & $398 \cdot 4$ & $204 \cdot 3$ \\
\hline Nucleated blood count $\left(\times 10^{y} / 1\right)$ & 9 & $10 \cdot 6$ & 3.6 & 45 & $10 \cdot 9$ & 3.7 \\
\hline Log reticulocytes $(\%)$ & 9 & $1.9(7)$ & $0 \cdot 4$ & 4 & $2(10)$ & $0 \cdot 6$ \\
\hline $\log (\mathrm{HbF}+1) \%$ & 9 & $1 \cdot 4(4)$ & $0 \cdot 8$ & 43 & $1 \cdot 5(5)$ & $0 \cdot 6$ \\
\hline Log bilirubin $(\mathrm{mmol} / \mathrm{l})$ & 8 & $1 \cdot 2(4)$ & 0.5 & 41 & $1.4(5)$ & 0.6 \\
\hline
\end{tabular}

Antilog of the mean.

Patients and methods

Serum samples from 108 unselected patients with homozygous sickle cell disease were studied. All patients were Jamaican of mainly African descent. Seventy one patients were men, 37 women. Their median age was 25 years (range 11-39 years). All patients were regularly attending the sickle cell clinic of the University Hospital, Kingston, Jamaica. At the time of venepuncture all patients were in a steady state-that is, without acute complications. No transfusions had been given in the three months before the study began.

The control group consisted of 116 healthy subjects with normal AA haemoglobin. Seventy four were men, 42 women. The median age was 26 years (range 18-43 years). All patients and controls were analysed for antibodies to dsDNA and ENA using an enzyme linked immunoabsorbent assay (ELISA) and counter immunoelectrophoresis) respectively. The ELISA method described by Gharavi et al was used to measure antiphospholipid antibodies. ${ }^{7}$

For a comparison of the clinical complications of antiphospholipid antibody positive and negative patients with sickle cell disease each antiphospholipid antibody positive patient was matched according to age and sex with five antiphospholipid antibody negative patients. The total clinical follow up was 484 months for the antiphospholipid antibody positive group and 2620 months for the negative group.

\section{Results}

Of the 108 patients with sickle cell disease nine (8\%) had increased levels of IgG antiphospholipid antibodies (range 5.5-15.6 U IgG); none of the 116 control subjects had increased levels of antiphospholipid antibodies ( $\chi^{2}$ test, $\mathrm{p}=0.0018$ ).

In four of the nine patients with positive sickle cell disease, frozen serum samples from previous years were available; all were positive

Table 2 Clinical features of nine anticardiolipin antibody (aCL) positive and 45 aCL negative patients with sickle cell disease matched for age and sex

\begin{tabular}{llllll}
\hline Clinical features & \multicolumn{2}{c}{$a C L$} & positive & & \multicolumn{2}{c}{$a C L$} & negative \\
\cline { 2 - 3 } \cline { 5 - 6 } & $n$ & $\%$ & & $n$ & $\%$ \\
\hline Severe painful crisis & $3 / 9$ & 33 & & $10 / 45$ & 22 \\
Acute chest syndrome & $3 / 9$ & 33 & & $4 / 45$ & 9 \\
Osteomyelitis & $0 / 9$ & 0 & & $1 / 45$ & 2 \\
Avascular bone necrosis $1 / 9$ & 11 & & $1 / 45$ & 2 \\
Arthritis & $0 / 9$ & 0 & & $3 / 45$ & 7 \\
Convulsions & $1 / 9$ & 11 & & $2 / 45$ & 4 \\
Spontaneous abortions & $1 / 3$ & 33 & & $2 / 15$ & 13 \\
Leg ulcerations & $3 / 9$ & 33 & & $19 / 45$ & 42 \\
\hline
\end{tabular}

One female sickle cell patient was prepubertal. 
for anticardiolipin antibodies. None of the 108 patients with sickle cell disease and 116 controls was positive for antibodies to ENA or dsDNA.

A comparison of the haematological and clinical features of patients with sickle cell disease with positive and negative antiphospholipid antibodies did not highlight any differences-that is, patients with sickle cell disease with antiphospholipid antibodies did not show any features of increased haemolysis (table 1), nor evidence of more frequent clinical complications (table 2).

\section{Discussion}

Several studies have established a strong association between antiphospholipid antibodies and arterial or venous thrombosis, or both, fetal loss, and possibly thrombocytopenia. ${ }^{12}$ These antibodies occur in a variety of diseases, including autoimmune, ${ }^{8}$ infectious, ${ }^{9}$ malignant, ${ }^{10}$ and drug induced disorders. ${ }^{11}$ From this study it appears that antiphospholipid antibodies can also occur in haemolytic disorders such as sickle cell disease. The increased levels of antiphospholipid antibodies cannot be explained by intercurrent infections as serial samples in all patients were positive.

Antiphospholipid antibodies show an affinity for the negatively charged phospholipids, which are located on the inner leaflet of the bimolecular lipid membrane of platelets. ${ }^{12}$ As the cell membranes of platelets and red blood cells have a similar phospholipid composition and distribution, ${ }^{13}$ an immune reaction may be anticipated in diseases characterised by the perturbation and destruction of red cell membranes such as sickle cell disease. In patients with sickle cell disease with a high concentration of irreversibly sickled cells, antibodies may be formed through chronic exposure to negatively charged phospholipids.

Alternatively, the production of antiphospholipid antibodies may be a part of a wider autoimmune disorder, present in some patients with sickle cell disease. Indeed, patients with sickle cell disease show various immunological abnormalities including abnormal immunoglobulin and complement levels, ${ }^{14}$ decreased phagocytic function, ${ }^{15}$ and splenic dysfunction. ${ }^{16}$ Systemic lupus erythematosus may be more common in sickle cell disease than in the general population. ${ }^{17}$ The patients with sickle cell disease with increased levels of antiphospholipid antibodies did not show signs of nephritis, arthritis, skin rashes, or other features of a connective tissue disease, however. Also, none of these patients was positive for antibodies to ENA or dsDNA.

Whatever the aetiopathogenesis of antiphospholipid antibodies in sickle cell disease, patients with sickle cell disease with these antibodies did not show any more serious disease course than patients with sickle cell disease without antiphospholipid antibodies. The haemolytic rate also appeared to be similar in the two groups. This is in agreement with the observation that antiphospholipid antibodies induce complications only at levels much higher than those observed in sickle cell disease.

In conclusion, this study provides further evidence that the high levels of antiphospholipid antibodies found in patients with systemic lupus erythematosus and other connective tissue disorders, but not found in patients with sickle cell disease, are not merely secondary to cell breakdown.

1 Hughes G R V. Thrombosis, abortion, cerebral disease and the lupus anticoagulant. $B M \mathcal{F} 1983 ; 287$ : 1088-9.

2 Asherson R A, Harris E N. Anticardiolipin antibodies: clinical associations. Postgrad Med F 1986; 62: 1081-7.

3 Milner P F, Jones B R, Dobler J. Outcome of pregnancy in sickle-cell anaemia and sickle-cell haemoglobin $\mathrm{C}$ disease. Am $\mathcal{F}$ Obstet Gynecol 1980; 138: 239-45.

4 Portnoy B A, Herion J C. Neurological munifestations in sickle-cell disease. Ann Intern Med 1972; 76: 643-52.

5 Powers D, Wilson B, Imbus C, Pegelow C, Allan J. The natural history of stroke in sickle-cell disease. $\mathrm{Am} \mathscr{\mathcal { F }} \mathrm{Med}$ 1978; 65: 461-71.

6 Lubin B, Chiu D, Bastacky J, Roelofson B, van Deenen L L M. Abnormalities in membrane phospholipid organisation in sickled erythrocytes. $\mathcal{F}$ Clin Invest 1981; 67: 1643-9.

7 Gharavi A E, Harris E N, Asherson R A, Hughes G R V. Anticardiolipin antibodies: isotype distribution and phospholipid specificity. Ann Rheum Dis 1987; 46: 1-6.

8 Harris E N, Gharavi A E, Hughes G R V. Antiphospholipid antibodies. Clin Rheum Dis 1985; 11: 591-609.

9 Schleider M A, Nachmann R L, Jaffe E A, Coleman M A Clinical study of the lupus anticoagulant. Blood 1976; 48: 499-509.

10 Levine S R, Diaz I M, Deegan M J, et al. Recurrent stroke associated with thymoma and anticardiolipin antibodies. associated with thymoma and
Arch Neurol 1987; 44: 678-9.

11 Zarrabi M H, Zucker S, Miller F, et al. Immunologic and coagulation disorder in chlorpromozine treated patients. Ann Intern Med 1979; 91 : 194-9.

12 Khamashta M A, Harris E N, Gharavi A E, et al. Immune mediated mechanism for thrombosis: antiphospholipid antibody binding to platelet membranes. Ann Rheum Dis 1988; 47: 849-54.

13 Cohen P, Derksen A. Comparison of phospholipid and fatty acid composition of human erythrocytes and platelets. $\mathrm{BrF}$ Haematol 1969; 17: 359-71.

14 Millard D, De Ceulaer K, Vaidya S, Serjeant G R. Serum immunoglobulin levels in children with homozygous sickle cell disease. Clin Chim Acta 1982; 125: 81-7.

15 Hernandez D E, Gonzales N, Rios R, Merchan L, Wuani H Phagocytosis in patients with sickle cell disease. F Clin Lab Immunol 1983; 12: 137-40.

16 Pearson H A, Spencer R P, Cornelius E A. Functional asplenia in sickle-cell anemia. $N$ Engl $\mathcal{F}$ Med 1969; 281 923-6.

17 Wilson W A, Nicholson G D, Hughes G R V, Amin S, Alleyne G A O, Serieant G R. Systemic lupus erythematosus and sickle-cell anaemia. $B M \mathcal{F} 1976$; i: 813 . 